\title{
QUASI-MANORIAL RIGHTS \\ IN ANCIENT INDIA
}

BY

\author{
LALLANJI GOPAL \\ (University of Allahabad)
}

There is no indication that in ancient India cultivators were tied to the soil like the European serfs. They enjoyed the freedom to migrate to another state if they were oppressed ${ }^{1}$ ). This right is implied in the texts of the early medieval period. Thus, the Brbannaradiya Purana (c. A.D. $750-900)^{2}$ ) says that when much afflicted by the sufferings caused by famine and taxation people feel distressed and migrate to countries rich in wheat and barley. A verse in the Subbäsitaratnakosa of Vidyākara ( $12^{\text {th }}$ century) ${ }^{3}$ ) speaks of men in a village leaving it when oppressed by the feudal chief. In the entire range of Sanskrit literature the only reference suggesting some form of manorial right which we have been able to trace is in the Upamitibbavaprapañcakathä of Siddharși (A.D. 906) ${ }^{4}$ ). In a city described as the fief (bbukti) of a certain king Karmma-parināma the entire population is said to have been thrown into cells and kept huddled together for a long time ${ }^{5}$ ). Another king named Sadāgama from time to time liberated some of these people and settled them in another city which could not be approached by Karmmapariñāma. In this way the population under king Karmma-parināma would have thinned, but his sister brought people from another city to take the places of those whom Sadāgama had liberated.

I) Mahäbbärata, XII. 89.24 .

2) (Ed. P. H. Sastri, Calcutta, I89r) XXXVIII. 87.

3) (Ed. D. D. Kosambi and V. V. Gokhale, Harvard, 1957) v. I I75. The position seems to have hardly changed even in the time of Bābur who observes that "in Hindustan hamlets and villages, towns indeed, are depopulated and set up in a moment! If the people of a large town, one inhabited for years even, flee from it, they do it in such a way that not a sign or trace of them remains in a day or a day and a half" - The Bäbur-näma tr. A. S. Beveridge, London, I92 r, II, p. 488.

4) (Ed. P. Peterson, Calcutta, I899) Pp. $176-78$.

5) Apavarakeșu niksipya sampinditāb sakala-kälam dhäryante. 
In the early medieval period, however, we find signs of serfdom and of manorial villages in some parts of northern India ${ }^{1}$ ). The earliest known reference is in the Nirmand (Kangra) copper plate inscription of mabäsämanta mahäräja Samudrasena ${ }^{2}$ ) which can be assigned roughly to the seventh century A.D. Samudrasena grants to a body of brāhmanas a village together with its inhabitants (sa-prativäsi-jana-sametam).

A stray plate from Nanana (Marwar) ${ }^{3}$ ), belonging to the twelfth century, records certain persons being granted or permanently allotted to the god Tripuruṣa. It is clear from the plate that these people were not slaves but independent persons including cultivators, songstresses and musicians. Section I records that a flute player (vämsika) named Lhaudiyāka was allotted to the deity. In section II we read of two persons named Śilapati and Sripāla, who were probably engaged in working the araghațta (Persian wheel) at Devananditagrāma, being allotted to the same god along with several other persons who probably lived in the locality where the temple stood. These were six songstresses, a suravala (a type of singer), a panavika (drum-player), a doyaraka (another class of singer), a mrdaniga-player and a flute-player. All these are named individually. Section VI records that mabäräjädbiräja Ratnapāla (of the Cāhamāna family of Nadol) gave away a certain Noriyāka

I) U. N. Ghoshal, Contributions to the History of the Hindu Revenue System (Calcutta, 1929) and The Agrarian System in Ancient India (Calcutta, 1930), does not take any notice of this question. B. P. Mazumdar, Socio-Economic History of Nortbern India (1030-II94 A.D.), Calcutta, 1960, is also silent about it. The recent standard works on the early medieval period (R. C. Majumdar and A. D. Pusalker Ed., The Age of Imperial Kanarj and The Struggle for Empire) including studies of dynasties and regions in the period also neglect this problem. D. D. Kosambi, An Introduction to the Study of Indian History (Bombay, I956), p. 298 gives a few references. It is, however, to be noted that the Neulpur (Cuttack) grant of king Subhākara (E.I., XV. I ff, ${ }_{3} G_{3}$ ) which may be assigned to the latter half of the 8th century does not refer to the "giving" of village workmen. Probably Kosambi bases his view on the expression sarva-satvänäñca occurring in line 9. But the context leaves no doubt whatsoever that the inhabitants were not granted and that the inscription refers to the grant as having been for the increase of the merit of all created being, along with that of the donor and that of his parents. R. S. Sharma (J.I.H., XXXIX, 3 10) notices the prevalence of the practice of granting villages along with the inhabitants in Orissa and in the Candella kingdom.

2) J. F. Fleet, C.I.I., III, no. 80, 1. 10.

3) E.I., XXXIII. $244 \mathrm{ff}$. 
together with his family. In section VII mabäräjaputra-kumāra Sāhaṇapāla is said to have granted to the temple in V.S. II92 (A.D. II35) two agriculturist householders (kutumbikas) formerly living at the village of Namdānāa, together with their sons and grandsons so long as they lived ${ }^{1}$ ). Section VIII records that mabäraja Ālhanadeva granted in V.S. I 205 (A.D. I 448) two agriculturist householders (kutum=kutumbikas) who were formerly living in the village of Namiānāa and also certain brothers whose names cannot be made out, and who, as the word is in the plural, must have been more than two in number.

A Caulukya grant dated A.D. 1207 from Timana (Bhaunagar) ${ }^{2}$ ) records that the Mehara king Jagamalla established two lingas and consecrated to them is pātbas ${ }^{3}$ ) of cultivated and fallow land in a certain village, also giving is päthas of land in another village. For his spiritual merit the donor is said to have given three men to be cultivators of the land granted by himself ${ }^{4}$ ). Their names are recorded as Saümsariyaiu, the son of a certain husbandman (kutumvika), Pañcakula Cāndạpa, and Cāiyã, the son of a Kolika.

From a number of inscriptions from Orissa ${ }^{5}$ ) we learn that the king

I) D. Sharma, Early Chauban Dynasties (Delhi, I959), p. 299, notices only this part of the grant. See also ibid., Appendix G (iii), 1. 20.

2) I.A., XI. $337 \mathrm{f}$.

3) According to H. H. Wilson, Glossary of Judicial and Revenue Terms, s.v., pätha, one pätba $=240$ sq. $\mathrm{ft}$.

4) Ete trayo janäb pradattäb kutumvikatvena.

5) For the grants of the kings of the Bhauma-Kara dynasty, founded in the middle of the eighth century A.D., see Terundia (Puri) plate of Subhākara II-E.I., XXVII. 21 5 f; Hindol plate of Subhākaradeva III (year ro3)-B. Misra, Orissa under the Bhauma kings, Calcutta, 1934, p. I 5 , ll. I 8 f; Dhenkanal plate of Tribhuvanamahādevi I (year I IO)-J.B.O.R.S., II. 42 I ff, 1. 28; Talcher plate of Subhäkaradeva IV (year I 4 I)-B. Misra, loc. cit., p. $36,1.37$ (here the expression is abridged as sa-saundikádiprakttikab); Talcher plate of Sivakaradeva (year I 49)-B. Misra, loc. cit., p. 44, 1. 24; also ibid., p. 5 r; Santigrama (Cuttack) grant of Dandimahädevi-E.I., XXIX. $87 \mathrm{ff}$; Ganjam grant of Daṇimahādevi-E.I., VI. I4I f; Ganjam grant of Daṇdimahādevi (year I 80)-E.I., VI. 137 ff; Kumurang (Puri) plate of Daṇuimahādevi (year 187)-B. Misra, loc. cit., p. 63, 1. 3x; Taltali (Cuttack) plate of Dharmma-mahädevi-I.H.Q., XXI. 219, 1. 32. The grants made by the feudatories of the BhaumaKaras also contain this expression. For the Bhañjas see Adilpur (Mayurbhanj) plate of Narendrabhañjadeva-E.I., XXV. I $59 \mathrm{f}, 11$. I $7 \mathrm{f}$. For the Sulkis see the $\mathrm{D}$ hen kanal grants of Jayastambhadeva-J.B.O.R.S., II. $4 \mathrm{I} 3 \mathrm{ff}, 1.20$; II. $406 \mathrm{ff}, 1$. I3. 
claimed some sort of ownership over men of certain occupations and crafts and would often transfer his right over them ${ }^{1}$ ). In these records the stock list of the rights accompanying the grant includes those over weavers (tantravayya or tantuväya), milkmen (gokuta or goküta) ${ }^{2}$ ), distillers $\left(\right.$ saundhika or saundika) ${ }^{3}$ ) and other subjects $\left(\right.$ prakrtika) ${ }^{4}$ ). That it was not a theoretical claim but had practical application would follow from set II of the Kendupatna plates (Śaka I217=A.D. I295) of Narasimha $\mathrm{II}^{5}$ ). This records that king Narasimha donated to Bhimadevaśarman several plots measuring 100 vätikäs of land and as a part of this donation (etacchäsanasyängatayā) granted as servants and subjects permanently attached (parajäb) seven men named in the record-a maker of conchshell bangles (sankbakära), a merchant ('́reștbin), a goldsmith (suvarnnakära), an oilman (tailika), a milkman (gopäla), a potter (kumbbakära) and another oilman (teli). The Dibbida (Vizagapatam) plates of Arjuna of the Matsya family (A.D. 1269) record the grant of a village which included a grant of the village artisans, the carpenter, goldsmith, barber, blacksmith, potter and sesamum-grinder. ${ }^{6}$ ) In the Kharepatan

I) B. Misra, op. cit., pp. 30, 95 takes these expressions to refer to additional taxes from the weavers, cowherds, distillers of spirituous liquors and all other tenants. $\mathrm{He}$ adds that the agricultural people who formed the majority of the population of a village are not mentioned because the gift of the village implied the bestowal of the right to enjoy the land taxes. The grant of the village did not expressly imply the taxes levied from weavers etc. and hence the rights to these taxes have been specifically mentioned. But uparikara is not used as a general term to cover the items that follow it. Uparikara, in other grants of ancient India also, appears as a specific item of revenue. The Orissa grants do not employ any term standing for the taxes from the professions mentioned in them; they clearly refer to the grant of persons following these professions.

2) B. Misra, op. cit., p. 95 suggests that the Oriya word gauda has been Sanskritised. R. S. Sharma, J.I.H., XXXIX. 3 to emends it as gokula.

3) The Dhenkanal grant of Jayastambha (J.B.O.R.S., II. $406 \mathrm{ff}, 1 . \mathrm{I}_{3}$ ) has kaivarta (boatman) in place of saundika.

4) Prakrti at times is found used in the narrow sense of men belonging to crafts and occupations formed into guilds. See Abbidbanacintamani of Hemacandra (in the Abbidhanasangraba, Vol. II, N.S.P., Bombay, Saka I8I8), III, v. 714-Prakertayab paurärạm śrenayo'pi ca.

s) E.I., XXVIII. I90-91.

6) E.I., V. 110-12, V. 22-Taksaka-svarnnakäraśca ksaurikạ karmmakärukab. Kulâlastilabamttã ca pradattā grämakärukāh. 
(Ratnagiri) plates (Śaka 930=A.D. 1008) ${ }^{1}$ ) Ratțarāja records that he assigned to his teacher families of female attendants (därikä-kutumbäni), a family of oilmen, a family of gardeners, a family of potters and a family of washermen.

The Bhatera (Sylhet) inscription (A.D. 1049) ${ }^{2}$ ) states that GovindaKeśavadeva donated to the god Siva 375 balas of land with 296 houses in various villages and also gave many attendant subjects who belonged to ordinary social groups and lived on the donated land (nañaparijanamstasmin janajatinanekasab). That the grant really carried with it a legal claim over the people inhabiting the houses and lands donated should be clear from the fact that the inscription devotes considerable space (lines 29 to 5I) to enumerating the different plots of land and houses in different villages. The inscription mentions the individual occupants of the houses by name; in some cases they are said to have been craftsmen, including cowherds, a bell-metal worker, a barber, a washerman, a boatman and an ivory-worker.

In the above-mentioned inscriptions the people who are attached to a deity as a religious grant are either agriculturist householders or men belonging to occupations which had a low social status. The term praja $^{3}$ ) or parijana employed for them is used in modern times in a sense which has to be distinguished from servants and slaves alike and stands for men of certain occupations who are in a way permanently

I) E.I., III. 297-302.

2) E.I., XIX. 279-86. In the Tezpur grant (J.A.S.B., IX, 1840, pp. 766 ff, v. 24) king Vanamāla is said to have made to the temple of Hātakeśvara Siva a gift consisting of villages, men, prostitutes and elephants.

3) This is sometimes pronounced parjä, or corruptly, purjab. It means progeny, offspring, subjects, people, tenants and dependants. In Cooch Behar it stands for a cultivator-at-will, who gets half the produce of the land, but is removable at the pleasure of the proprietor, to whom he is usually in debt for advances, and is more like a serf than a free agent. In Cuttack the term is applied to low castes, such as the barber, washerman, fisherman, weaver, leather-worker, and toddy tapper, who would formerly sometimes sell themselves and their families into slavery until they repaid the purchase-money. The children born during this period became the property of the purchaser, and, with their parents, might be bought, sold, or let out for hire. They lived apart from their masters. They did not forfeit their caste or forego their occupations, and retained a title to their hereditary possessionsH. H. Wilson, Glossary of judicial and revenue terms, s.v., prajā. 
associated with the chief of the village as his attendants ${ }^{1}$ ). As against these there are a few inscriptions in some parts of northern India which indicate that kings claimed some sort of ownership over the inhabitants of villages in their jurisdiction. Thus, in Assam we find that Vallabhadeva (A.D. I I 84-85) granted seven villages to an alms-house ${ }^{2}$ ) and the list of rights accompanying the grant includes that over the people living in them (sajanann). He also gave five persons, whose names are recorded, as assistants (sabayab), together with their wives and children (putra-dara-samanvitäb). In the Madanpur (Dacca) plate of Sricandra ${ }^{3}$ ), who ruled in Bengal towards the close of the tenth and the beginning of the eleventh century A.D., the land is granted along with the people (sa-prajā). A plate in the India Office ${ }^{4}$ ), on palaeographic considerations assigned to the eleventh or twelfth century, records that a certain king Vijayarājadeva ${ }^{5}$ ) granted to some people the cultivated lands, wells, houses and kutumbikals in the estate (paribboga) of Kesarikoțta which were not enjoyed by Mūladeva ${ }^{6}$ ), and a village along with its bipeds (dvipada), quadrupeds (catuspada), fields and kutumbikas ${ }^{7}$ ). The Candella grants are more clear in this respect. The donated villages are described as carrying with them the right over the artisans, cultivators and merchants living in them ${ }^{8}$ ).

As regards the status of the men said to have been attached to the

I) Cf. Krtyakalpataru of Lakṣmidhara, Vyavabärakända (Ed. K.V.R. Aiyangar, Baroda, 1953), p. 56-tad-adbina-kutumbinyab is explained as gopäla-saundikädi-striyab.

2) E.I., V. 183 ff, vv. I7, 22.

3) E.I., XXVIII. 56-58 dated in the year 44 of his reign.

4) E.I., III. 3 I 3 f.

5) There is nothing to connect him with any of the known dynasties of the period. It is even difficult to be certain about the region in which he ruled.

6) Most likely the name of a certain deity in a temple who possessed a major portion of the land in Kesarikoțta or else a feudatory chief.

7) The editor of the plate translates kutumbika as a house-slave, but we prefer the more usual explanation of an agriculturist householder.

8) Plates of Madanavarman dated A.D. I 136-E.I., XXXII. I $21-23,11.29-34-$ sa-käru-karsaka-vanig-västavyam. See R. S. Sharma, J.I.H., XXXIX. 310 . The Charkhari plate of Paramardin (E.I., XX, P. I3I, I. I9) has sa-kärukapanikavanigi-vāstavyam. The mistakes in the expression were not realised earlier and hence scholars had difficulty in explaining it-J.U.P.H.S., XXIII. 240, f. n. 33 . 
donee as a religious grant it is clear that they were not slaves but independent persons. They have also to be distinguished alike from serfs, if serfdom is conceived as a perpetual adherence to the soil of an estate owned by a lord. If performance of services for other persons is taken as the essence of the status of a $\operatorname{serf}^{1}$ ), the men of our inscriptions may be described as serfs, but only in a restricted sense. The comparison is probably closer with the villeins of the European manorial system which is associated with dependence of a population on a ruler, consisting not in ownership extending over persons nor in contractual arrangements, but in various forms and degrees of subjection, chiefly regulated by custom ${ }^{2}$ ). We find it difficult to determine the precise status of the men of our gtants. The records are totally silent about their obligations and the claims of the ruler. In one respect, however, their position seems to have been worse than the legal status of a villein or even a serf. Even if unfree a villein was not exposed to the arbittary will of his lord; he was not a slave and was not bought and sold apart from his holding. The serf was also not given over to his lord to be owned as a thing or an animal. The records which speak of the men being granted or attached to the donee as living on the land granted contemplate a position similar to that of the manorial system. But in some of the donations of the stray plate from Nanana and set II of the Kendupatna plates of Narasimha Il the men so attached are described as belonging to villages other than that granted. This would mean that in these cases the rulers transferred their rights over the subjects and attendants even without actually disposing of the land on

I) Encyclopaedia Britannica, s.v., serf.

2) Encyclopaedia Britannica, s.v., manor. In medieval England we find that the two standard tests to determine the status of a villein were uncertainty of services and the payment of merchet, though in practice the proof of villeinage was a very intricate matter, and one on which there was often much room for doubt-A. Lane Poole, Obligations of Society in the XII and XIII Centuries (Oxford, 1946), p. 14. But we have no means to find out if any such tests were applied in India. The essence of villeinage was labour service; the villein must work for his lord for so many days in the week in addition to boon works, special tasks, precaria, at certain seasons of the year-A. Lane Poole, loc. cit., p. Is. We may say that the Indian epigraphic references in the early medieval period also imply such obligations. 
which they dwelt, and in doing so could compel a man to move from one village to another ${ }^{1}$ ).

In medieval English society we find that there was a large and growing class of tenants who did not render any services, or did only insignificant services ${ }^{2}$ ). The Rajatarangini and some of the inscriptions of the early medieval period show that the obligation to do forced labour was not always performed but was sometimes commuted by some payment in cash or kind. These inscriptions ${ }^{3}$ ) describe the grant as accompanied by the right of utpadyamana-visti. It refers to the dues paid by the villagers in place of the forced labour they had to perform for the state. In Kashmir the system of forced labour appears as rüdbabbärodbi. The Rajataranigini suggests that it was not always necessarily the actual carriage of loads but might be commuted by some payment in cash or kind. King Sankaravarman is said to have introduced this system of forced labour. He fined the villagers failing to carry loads for one year, at the value of the load calculated according to the highest prices in the regions concerned ${ }^{4}$ ). In the reign of Harsa (A.D. I089IIOI) a certain temple was plundered, hence the members of the purobita corporation requested him to be exempted from riddhabbarodbi (forced labour) ${ }^{5}$ ). This reference also favours the suggestion that the forced labour was often commuted for payment in cash or kind.

In England we find that many a villein gained his liberty by escaping to a town where, if he remained unclaimed for a year and a day, he became free. A villein obtained his freedom also by entering the orders of the church. But the surest methods of obtaining manumission were by charter or by purchase, the money for which was provided by a third party, as the villein's property was in theory his lord's. Sometimes

1) Even in England many aspects of medieval serfdom were very like slavery. In theory, at least, a lord could do what he pleased with his villein except kill or mutilate him and there are occasional records which show that a lord could sell his villein to another-A. Lane Poole, op. cit., p. 14.

2) Ibid., p. 24 .

3) E.I., IX, no. I (B).

4) Räjatarangini, V. 172 ff.

s) Ibid., VII. I088; also ibid., VIII. 2513. 
freedom was granted in return for services rendered, for example going on crusade in place of his lord. The enfranchisement of a serf was a solemn and a public act. The investiture with the arms of a freeman, the spear and lance, was part of the formal ceremony of manumission ${ }^{1}$ ). We have no records to determine if there were in early medieval India also set rules for manumission or any formal ceremonies connected with it. We can, therefore, only conjecture the possibilities. It is obvious that a runaway villein if not recovered was in practice free. Likewise a master, if pleased with his villein, often might have freed him from his obligations. As we know that slaves in India could be emancipated if their purchase money was paid ${ }^{2}$ ), we can postulate a similar rule in the case of the Indian counterparts of villeins. We have some references to suggest that in India certain formalities were observed in connection with the manumission of a slave ${ }^{3}$ ). Similar formal ceremonies were probably performed at the time when a "villein" obtained his freedom.

It is, however, to be remembered that this type of tenure was not found alike in all parts of northern India. On the contrary it seems to have prevailed only in certain scattered areas, chiefly in Rajasthan, Orissa and Assam. Usually peasants and other villagers were free and masters of their own persons. Such a quasi-manorial system must have evolved as a response to the narrowing horizon of economic wants and political requirements. The decline in the volume of trade activity and the political insecurity resulted in giving an agricultural basis to the social and political life. The weakening of the central authority naturally resulted in the increase in the power of local chiefs and lords. The strengthened political power of local chiefs in certain areas was bound in the course of time to lead to the establishment of such manorial rights ${ }^{4}$ ).

There were certain tendencies in earlier times which helped the

I) A. Lane Poole, Op. cit., pp. 28-34.

2) Artba, III. I3; Närada, V. 29-38.

3) Näyädbammakabā (Bombay, I919), I, p. 2I; Vyavabärabbäsya, 6. 208.

4) R. S. Sharma, J.I.H., XXX. 3 Io suggests that "in Orissa it may have been found necessary on account of the scarcity of working population for running rural economy". 
emergence of a tenure resembling the manorial system. Even in the early legal texts we find that the king is given the power to exact forced or unpaid labour from artisans and labourers ${ }^{1}$ ). An early epigraphic testimony to the existence of visti is to be seen in the Junagadh inscription (A.D. I 50) of Rudradāman ${ }^{2}$ ). In the Arthaśästra (c. 300 B.C.300 A.D.) ${ }^{3}$ ) forced labour seems to have been a regular thing, which the state utilized to its best advantage, recording the labour rendered by each citizen. We get an idea of the nature of the work included under viști from the Kämasütra ${ }^{4}$ ) (c. $4^{\text {th }}-5^{\text {th }}$ century) which speaks of peasant women as being compelled to perform for the village headman unpaid work of various kinds, such as filling up his granaries, taking things into or out of his house, clearing or decorating his residence, working in his fields, and spinning yarn of cotton, wool, flax or hemp for his clothes. The obligation of the peasant to cultivate the state land in the form of vist $i$ is referred to in the commentary on the Mabäbhärata $a^{5}$ ). In the hands of local chiefs or donees, who were in a position to exploit the rural resources fully, the right to forced labour could be put to an effective use. The long list of rights accompanying the grants of the early medieval period indicates that, as opposed to earlier times when only revenues were given, now actual proprietory rights were transferred. The enumeration of these concessions, which often include rights over land, water, trees, forests and other similar things, suggests that properties which were customarily under the undefined enjoyment of villagers were increasingly being brought under the personal possession of donees.

The subjection of the people to the village chief may be traced back to the rights of the donee and the obligations of the residents in the

I) Gautama, X. 31-32; Manu, VII. 138; Viṣnu Dbarmasütra, III. 32; Agnipurāna, CCXXIII. 33 ; Sarikbalikbita q. in Vivädaratnäkare of Caṇ̣eśvara, Ed. J. Vidyasagara, Calcutta, 1887, p. 662.

2) D. C. Sircar, Select Inscriptions (Calcutta, I942), p. 372.

3) II. 35 .

4) V.s.s.

5) XII. 140. 21-Yab kinäsaḅ satam nivartanäni bbümeb karṣati tena viștirüpena räjakijyam api nivartana-dasakam karșaniyam suìyavad raksanīyam ca. 
village granted as they appear even in the earlier land-grants. In these records the villagers are required, besides paying their dues in cash and kind, to listen to the orders of the donee and to carry them out ${ }^{1}$ ), to perform personal services to him ${ }^{2}$ ) and to convey his messages ${ }^{3}$ ). Another earlier tendency which favoured the emergence of manorial tenure was the practice of letting out land to cultivators who received half the produce. Some early records would suggest that such men tilling land for half the crops were sometimes closely associated with the land granted and the grant was accompanied with a provision for these cultivators also. Thus, the plates of the Sälanikāyana Vijaya Devavarman (c. 320 A.D.) ${ }^{4}$ ), which record a grant of twenty nivartanas of land, mention along with it that a house-site was granted to cultivators who worked for half the crops (addhiya-manussanam). Likewise the Hirahadagalli plates of the Pallava king Sivaskandavarman (latter half of the third century A.D. ${ }^{5}$ ) also provide for such cultivators called here addhika. The land-grants often mention that the donees had the right to cultivate the land or get it cultivated. This right of subinfeudation implied that of ejecting an actual tiller of the soil, which in some cases must have reduced the peasants to the status of tenants-at-will.

It would appear that even by the fifth century there had come to emerge some form of manorial tenure in connection with the estates of religious establishments ${ }^{6}$ ). Fa-hsien (c. 405-4II A.D.) ${ }^{7}$ ) says that,

I) E.I., II, no. 30; IX, nos. 21, 39; XXIII, nos. 3, 9; C.I.I., III, nos. 25, 26, 40.

2) E.I., XXVIII, no. 2.

3) E.I., XII, no. 17.

4) E.I., IX, no. 7.

s) D. C. Sircar, Select Inscriptions, p. $44^{\circ}$.

6) The land-grants to temples and monasteries are sometimes specifically said to have been made to meet the expenses of presenting unguents, flowers, fragrant materials, lamps, music and offerings to the deity, repairing the temple, maintaining the priests and feeding the poor, the sick, the old and ascetics-E.I., XII, no. 7; VI, no. 29; XVII, p. I Io; XXVII, no. 3 ; XXI, no. 43; C.I.I., III, no. 25. Generally the expenses on these items were met out of the revenues from the land-grant. It is, however, not unlikely that in some cases the villagers were either individually required to provide for a specific item, or paid their share of all these items. Some of these services probably helped in the crystallisation of manorial obligations.

7) Cbinese Literature, 1956, no. 3, p. I 33. 
after the Nirvanna of the Buddha, the kings, elders and lay Buddhists built monasteries for the monks and provided them with houses, gardens and fields, with husbandmen and cattle to cultivate them. The history of feudalism in north India indicates that secular landgrants to officers and vassals probably took the religious grants as their prototypes ${ }^{1}$ ). We may suggest a parallel development from religious examples in the case of manorial rights of secular chiefs of villages.

The villeins formed the largest group in the structure of society in medieval England, representing in association with the smaller peasantry approximately 70 per cent of the population ${ }^{2}$ ). After the Norman Conquest, economic and humanitarian motives, both the convenience of the masters and the preaching of the Church, worked for the abolition of slavery in the proper sense of the term. The emancipation of a large number of slaves affected the social position of the class into which these were thrust and tended to drag down the villeins, who now became the lowest class, on the downward path to serfdom ${ }^{3}$ ). But in India we do not find such a situation. There always existed a class of slaves and landless labourers below the peasants. In England the sharp distinction between freeman and villein begins to emerge in the twelfth century with the growth of royal writs and possessory assizes. The king did not wish to interfere with the private jurisdiction which a lord had over his villeins and so it became necessary to decide who could and who could not get the protection of his rights and property in the king's court $\left.{ }^{4}\right)$. But we do not find in early medieval India any practical need or juristic keenness to determine the status of peasants. Here the class of slaves existed as distinct from all other social groups ${ }^{5}$ ).

The reason why the manorial system did not become widespread

ı) J.E.S.H.O., IV. 103.

2) A. Lane Poole, Op. cit., p. I 2.

3) Ibid., pp. $12 f$.

4) Ibid., p. I 3 .

5) It is, however, likely that the transformation of the sundras into cultivators from the Gupta period onwards (R. S. Sharma, Position of Südras in ancient India) gradually brought about the depression of the earlier economically and socially backward peasants to a status resembling that of villeins. 
in India was that there was not a total collapse of imperial machinery and commercial intercourse. We know that several empires rose in different parts of the land and generally managed to preserve the administrative machinery in some form or other. Moreover, commercial intercourse between different parts of India, though it slackened and lessened, was still considerable in volume. Thus, there was not any great need for building up a new social and political system in the form of manors. It is to be noted that the epigraphic records which testify to manorial tendencies belong chiefly to regions which represented backwaters in the economy of north India. 